African Crop Science Journal by African Crop Science Society is licensed under a Creative Commons Attribution 3.0 Uganda License. Based on a work at www.ajol.info/ and www.bioline.org.br/cs DOI: http://dx.doi.org/10.4314/acsj.v26i3.6

\title{
RESISTANCE OF UGANDA SOYBEAN GERMPLASM TO ADZUKI BEAN BRUCHID
}

\author{
U.M. MSISKA, T.L. ODONG, M. HAILAY, B. MIESHO, S. KYAMANYWA, P.R. RUBAIHAYO \\ and P. TUKAMUHABWA
}

\author{
Department of Agricultural Production, College of Agricultural and Environmental Sciences, \\ Makerere University, P. O. Box 7062, Kampala, Uganda \\ Corresponding author: ulemsiska@gmail.com
}

(Received 16 July, 2017; accepted 10 August, 2018)

\begin{abstract}
Soybean (Glycine $\max$ (L.) Merrill) is among the major food and industrial crops grown globally for its high protein and oil content. Lately, in Uganda, soybean reportedly faces challenges with a storage pest, Callosobruchus chinensis. This study was carried out to quantify the damage caused by the pest and identify the sources of resistance in the germplasm in Uganda. The study was conducted at Makerere University Agricultural Research Institute, Kabanyolo (MUARIK) in Uganda, during 2015 and 2016. Callosobruchus chinensis was used to challenge 498 soybean lines under no choice condition, in the laboratory. Results showed no significant differences in eggs laid amongst the different genotypes; however the genotypes performed significantly different $(\mathrm{P}<0.05)$ for adult insect emergence, median development period (MDP), Dobie susceptibility index (DSI), growth index (GI), insect percent emergence (\% IE) and seed weight loss (\%WL). Genotype AVRDC G8527 had the lowest \% IE (6.31), DSI (0.7), \% WL (0.02) and GI (0.07), suggesting high resistance. Weight loss of up to $27 \%$ was recorded in genotype USA 7. There was a strong positive correlation between number of adults that emerged with DSI ( $r=0.87)$, eggs $(r=0.88), \%$ weight loss $(r=0.73)$, and growth index $(r=0.996)$. Cluster analysis revealed that AVRDC G8527, a resistant genotype was closely related to S-line 13.2A, a moderate resistant genotype. Regression analysis, revealed that adult bruchid emergence explain seed weight loss with $62 \%$ coefficient of determination; while seed colour could be used to determine genotype DSI with up to $74 \%$ coefficient of determination. Genotypes AVRDC G8527 and G89 were identified as the most resistant genotypes based on levels of DSI.
\end{abstract}

Key Words: Callosobruchus chinensis, Dobie susceptibility index, seed weight loss

\section{RÉSUMÉ}

Le soja (Glycine max (L.) Merrill) est parmi les cultures alimentaires majeures et industrielles cultivées généralement pour sa grande teneur en protéine et en huile. Récemment, en Ouganda, le soja fait face à des défis avec une peste de stockage, Callosobruchus chinensis. Cette étude a été conduite pour quantifier les dommages causés par la peste et identifier les sources de résistance dans le germplasm en Ouganda. L'étude a été conduite à l'Institut de Recherche Agricole de l'Université de Makerere, Kabanyolo (MUARIK) en Ouganda, en 2015 et 2016. Callosobruchus chinensis a été utilisé pour évaluer 498 lignées du soja sous une condition sans choix, dans le laboratoire. Les résultats ont montré qu'il n'y a pas de différences significatives dans la ponte des œufs parmi les différents génotypes; toutefois, les génotypes ont montré des performances significativement différentes $(\mathrm{P}<0,05)$ pour l'émergence des insectes adultes, la période moyenne de développement (MDP) l'indice de sensibilité de Dobie (DSI), l'indice de croissance (GI) ; le pourcentage d'émergence de l'insecte (\%IE) et la perte du poids 
(\%WL). Le génotype AVRDC G8527 a eu le plus faible \%IE (6,31), DSI (0,7), \%WL (0.02) et (0.07) suggérant une grande résistance. Une perte de poids jusqu'à $27 \%$ a été observée sur le génotype USA 7 . Il y a une forte et positive corrélation entre le nombre d'adultes qui ont émergé avec DSI $(r=0,88)$, la perte du poids $(r=0.73)$, et l'indice de croissance $(\mathrm{r}=0,996)$. L'analyse hiérarchique a révélé que AVRDC G8527, un génotype résistant a été lié à la lignée S-line 13.2A, un génotype modérément résistant. L'analyse en régression linéaire a révélé que l'émergence du bruche adulte explique la perte du poids avec un coefficient de détermination de $62 \%$; alors que la couleur des graines pourrait être utilisée pour déterminer le DSI jusqu'à $74 \%$ de coefficient de détermination. Les génotypes AVRDC G8527 et G89 ont été identifiés comme génotypes les plus résistants sur la base des niveaux de DSI.

Mots Clés: Callosobruchus chinensis, indice de sensibilité de Dobie, perte du poids de la graine

\section{INTRODUCTION}

Bruchids are the most important insect pests of stored grain legumes, because their damage starts in the field and continues along the value chain. Damage by bruchids is irreversible and direct on the grain (Kananji, 2007). Due to the bruchids' high fertility, ability to re-infest and short generation times, even low initial infestation rates can lead to tremendous damage (Yamane, 2013). Bruchids cause overall seed weight loss, loss of seed viability and altered nutritional quality due to the presence of insect frass, excrement and dead insects in and on the seed. A single beetle is able to cause $3.5 \%$ weight loss in cowpea seeds (Tembo et al., 2016).

In cowpea (Onyido et al., 2011) and beans (Credland, 2000), losses of up to $100 \%$ have been reported after 3-6 months of storage. However, it is important to note that losses due to bruchids vary from crop to crop (Kananji, 2007; Swella and Mushobozy, 2009). Although bruchids are known to attack many legume species, literature indicates that there is lack of information regarding damage caused to soybean by bruchids. Most previous reports have been done on other legumes such as cowpea, chickpea (Sharma and Thakur, 2014a) and common beans (Kananji, 2007); but little is documented for soybean, suggesting that damage on soybean by bruchids has previously been considered negligible. Nevertheless, Tukamuhabwa (2015, soybean breeder, Makerere University Agricultural Research Institute personal communication) indicated that soybean was being seriously damaged by bruchids in some parts of Uganda.

One of the major bruchid attacking stored legumes is Callosobruchus chinensis, commonly called adzuki bean weevil or chinese bruchid (Spradbery, 2013). A record of $C$. chinensis in Uganda was first published in 1978 by Nyira, then in 1995 by Nahdy on pigeon peas (Nahdy, 1995).

Realising how damaging bruchids can be on legumes, different control methods have been undertaken by farmers; of which pesticides have been the principal means (Dent, 2000). However, pesticides have drawbacks associated with their use such as pest resistance, destruction of beneficial insects, environmental contamination and hazards to the user; in addition to them being expensive for subsistence farmers (Dent, 2000). Resistant varieties, therefore, would provide a sustainable environment friendly method to reduce soybean pre- and post-harvest losses due to $C$. chinensis, and assist farmers as well as processors in storing their soybeans for long periods. In Uganda, soybean germplasm has not been explored for resistance to storage pests. No cultivar of soybean showing resistance to storage pests has been released so far in the world (Bansal et al., 2013).

The existence of genotypic variations in response to bruchid infestation reported in some legume species, such as cowpea (Deshpande, 2011), pigeon peas (Affognon et al. 2016), rice beans (Somta et al., 2006), chickpeas (Kar and Ganguli, 2016) and mungbean (War et al., 2017) was associated 
with physical and chemical signals by the adult female to detect diets that will provide better larva development and higher nutritive value (War et al., 2017). Unfortunately, such studies have not been extensively done on soybean.

The objective of the study was to assess damage caused and identify sources of resistance to bruchids (Callosobruchus chinensis) in soybeans germplasm available in Uganda.

\section{MATERIALS AND METHODS}

Study area. The study was carried out in 2015 and 2016 at Makerere University Agricultural Research Institute, Kabanyolo (MUARIK) in Central Uganda. MUARIK is located between longitude $32^{\circ}$ 37E, Latitude $0^{\circ} 28 \mathrm{~N}$ at an altitude of $1200 \mathrm{~m}$ above sea level (Sserumaga et al., 2015). The area receives mean annual rainfall of $1150 \mathrm{~mm}$ and has mean temperature of $21.5^{\circ} \mathrm{C}$ (Fungo et al., 2011).

Bruchid rearing. Adult bruchids used in this study were from a culture established in a laboratory at MUARIK. The bruchids which initiated the culture were collected from the National Crop Resources Research Institute (NaCCRI) soybean stores in Namulonge in Uganda. The laboratory culture was established at MUARIK by allowing the collected samples of insects to oviposit on three susceptible commercially grown varieties (Maksoy 2N, Maksoy 3N and Maksoy 4N). The insects were reared on 1 and $5 \mathrm{~kg}$ of seed placed in $1 \mathrm{~L}$ Kilner glass jars and $10 \mathrm{~L}$ plastic buckets, respectively. The jars and buckets were capped with muslin cloth to allow ventilation, but prevent insects from escaping. The populations were maintained by regularly transferring the bruchids to new grains. A sample from the reared bruchid population was confirmed to be Callosobruchus chinensis by the National Agricultural Research Laboratories (NARL), Kawanda in Uganda using diagnostic protocols by Farrell et al. (2015).
Soybean germplasm collection. A total of four hundred and ninety eight lines from Uganda (321), introductions from USA (56), AVRDC-Taiwan (110) and Zimbabwe (11) available in the germplasm collection of Makerere University Soybean Breeding and Seed Systems Programme were used in the study. The seed samples were oven-dried at $30^{\circ} \mathrm{C}$ for 24 hours, to ensure that any eggs or adult insects from the field were killed (Amusa et al., 2014). The samples were then removed from the oven and placed in laboratory shelves under room conditions for 7 days (Kananji, 2007).

Research design. A sample of 100 soybean seeds was drawn from each of the 498 genotypes and weighed to give baseline information of 100 seed weight. Subsequently, samples of 50 seeds each were placed in different plastic petri dishes and weighed to determine the initial seed weight. The soybean seeds in each petri dish were artificially infested with 20 randomly selected adult bruchids of 1-3 day old, from the bruchid colony under the no-choice test method as described by Somta et al. (2008). Petri dishes were laid out in a randomised complete block design, with insect infestation days as blocks; and were replicated thrice. Bruchids were removed from the soybean samples after 10 days (Kananji, 2007).

Data collection. Eggs laid on each of the 50 seeds were counted on day 11 (Kananji, 2007) and emerging adult insects were counted and removed daily until there was no new insects emergence for 5 consecutive days (Lephale $e t$ al., 2012). Then final weight of seed samples in each petri dish was taken. Total number of eggs laid was taken as an indicator for oviposition (Amusa et al. 2014); while the number of bruchid emergence was taken as an indicator for magnitude of infestation (Emeka, 2010). From these data, the following variables were derived: 
(i) Grain weight loss \%, which is an economic loss indicator (Amusa et al., 2014), was calculated as follows:

Grain weight loss

$(\%)=\frac{100 \times(\mathrm{IGW}-\mathrm{FGW})}{1 \mathrm{GW}}$

Where:

FGW = final grain weight, IGW = initial grain weight for the sample.

(ii) Growth Index (GI), which is an indicator of genotype suitability for development of insects (Régnière et al., 2012) was calculated as:

$$
\mathrm{GI}=\frac{\% \mathrm{IE}}{\mathrm{MDP}}
$$

Where:

$\% \mathrm{IE}=$ Percent Insect Emergence and MDP = Median development period

The median development period (MDP) was calculated as the number of days from the middle of oviposition (d 5) to the first progeny emergence (Kananji, 2007).

(iii) Dobie susceptibility Index (DSI)

The data on the number of adult bruchid that emerged and the median development period were used to calculate the Dobie susceptibility index (Dobie, 1974) for each genotype using the formula:

$\mathrm{DSI}=\frac{\log _{\mathrm{e}} \mathrm{Y} \times 100}{\mathrm{t}}$

Where:
$\mathrm{Y}=$ total number of adult bruchid emerged, and $\mathrm{t}=$ median development period.

If no insect emerged over the test period, the Dobie susceptibility index value was equal to zero (DSI=0) (Derera et al., 2001). The modified susceptibility index ranging from 0 9 was used to classify the soybean genotypes; where, $0-1=$ resistant; $2-3=$ moderate resistant; 4 - 5 = susceptible and 3 - 6 highly susceptible. This is a modification from Dobie (1974), which has a range of 0 - 11. Dobie susceptibility Index was also modified by Kananji (2007) and Radha and Susheela (2014) so as to fit with the crops they were working on. The genotypes with high susceptibility indices (DSI) were considered susceptible and those with low susceptibility indices as resistant. This was based on the assumption that a few insect progenies would emerge out of a resistant genotype and insect progeny development would take a longer time in a resistant than in a susceptible genotype (Kananji, 2007).

Seed size determination. Seed size was categorised basing on Tukamuhabwa and Oloka (2016). Basing on this information, any genotype with 100 seed weight less than genotype Maksoy 1 was considered as small $(<12000 \mathrm{mg})$, genotype same as Maksoy 1 (12000-14000 mg) was categorised as medium; genotype of the same size as Maksoy 2 (14000-20000 mg) was considered as large and genotype with higher 100 seed weight than Maksoy 5 (>20000 mg) was considered very large. Four soybean seed size categories were determined.

Data analysis. Data were subjected to OneWay ANOVA, using GenStat Statistical Package 12th Edition. Where assumptions of Analysis of Variance were found to have been violated, data transformations were performed. Genotypes were then grouped into four categories, namely: resistant, moderate/ 
intermediate resistant, susceptible and highly susceptible using the ratings described above basing on the means of DSI. Frequency distributions and correlation coefficients ( $r$ ) were calculated for the parameters to determine relationships (Amusa et al., 2013). Hierarchical cluster analysis was carried out to determine relationships among genotypes. Cluster analysis grouped genotypes into classes according to their similarities basing on the morphological parameters. Similarities were calculated from each parameter using Euclidean test (Harding and Payne, 2012).

\section{RESULTS}

General observation on studied variables. The analysis of variance results for the parameters used to assess soybean resistance to Callosobruchus chinensis are presented in Table 1. Significant differences were observed $(\mathrm{P}<0.05)$ in 100 seed weight, initial weight, final weight, percent weight loss, adult emergence, Dobie susceptibility index, percent insect emergence, growth index and median development period; indicating genetic variability in the studied germplasm. However, genotypes did not show significant differences ( $P>0.05)$ on number of eggs laid on them.

Descriptive statistics of the studied parameters for 498 genotypes are presented in Table 2. The studied germplasm was genetically diverse and showed greatest variability on percent seed weight loss $(\mathrm{CV}=56.99 \%)$, followed by growth index $(\mathrm{CV}=50.52 \%)$; while median development period showed least variability $(\mathrm{CV}=11.67 \%)$. The calculated single variable percent coefficients of variation indicated that percent seed weight loss in soybean germplasm was more dispersed than DSI.

Relative susceptibility. Figure 1 presents DSI ranges of the studied 498 genotypes. Less than $1 \%$ of the genotypes were resistant, $19.08 \%$ of the genotypes showed moderate resistance, $54.82 \%$ were susceptible and $25.5 \%$ were highly susceptible indicating genetic variability

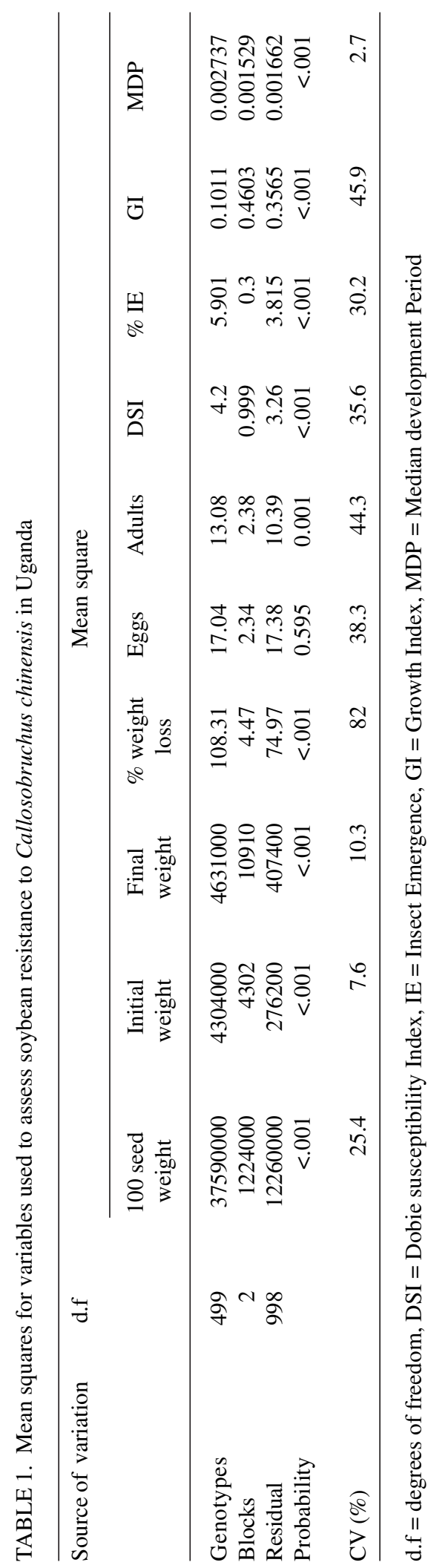


in the studied germplasm. Predominant DSI was 4. Genotype AVRDC G8527 had the lowest DSI (0.704), followed by Introduction G89 (1.67), whereas AVRDC G 2043 had the highest DSI (8.14) (Table 4).

Seed size and seed coat colour. The results on seed size of the studied genotypes based on 100 seed weights are presented on Table 3. From the studied genotypes, $56.24 \%$ had their 100 seed weights above the experimental mean of $13,898 \mathrm{mg}$. Most of the genotypes (43.17\%) were large seeded; followed by medium seeded $(39.76 \%)$ genotypes. The largest seeded genotype was AGS 329 (26481 mg); followed by AGS 292 (22367 mg); whereas the smallest

TABLE 2. Descriptive statistics of studied parameters for 498 soybean genotypes in Uganda

\begin{tabular}{lrccc}
\hline Parameter & Mean & Minimum & Maximum & CV (\%) \\
\hline 100 seed weight (mg) & 13865 & 5225 & 26481 & 18.00 \\
Initial seed weight (mg) & 6942 & 2713 & 13538 & 17.29 \\
Final seed weight (mg) & 6220 & 2309 & 12322 & 20.00 \\
Number of eggs laid & 136.10 & 24 & 312.30 & 37.88 \\
Adult emergence & 64.53 & 2.67 & 172.30 & 47.91 \\
Insect emergence (\%) & 45.36 & 6.31 & 90.67 & 33.82 \\
Seed weight loss (\%) & 10.47 & 0.02 & 27.18 & 56.99 \\
DSI & 5.07 & 0.70 & 8.14 & 23.35 \\
Growth index & 2.09 & 0.07 & 5.75 & 50.52 \\
MDP & 31.58 & 18.67 & 43.33 & 11.67 \\
\hline
\end{tabular}

DSI = Dobie Susceptibility Index; MDP = Median Development Period

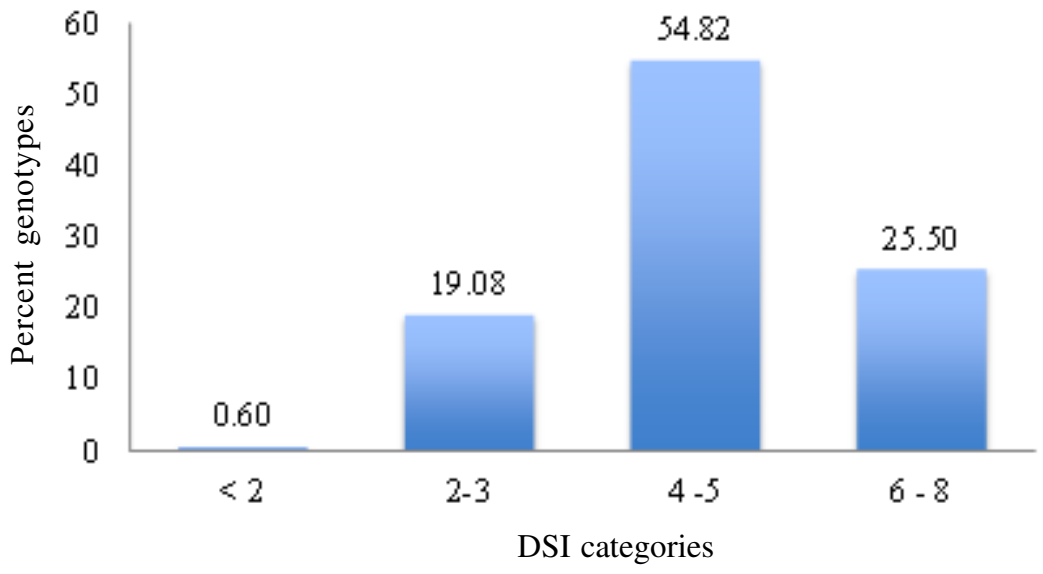

Figure 1. Percent genotypes for the 4 Dobie Susceptibility Indexes (DSI) categories in a soybean study in Uganda.

TABLE 3. Seed size categories of the studied soybean genotypes in Uganda

\begin{tabular}{llcc}
\hline Category & \multicolumn{2}{c}{ Range $(\mathrm{mg})$} & Genotypes $(\%)$ \\
\cline { 2 - 3 } Small & 5000 & $<12000$ & 15.66 \\
Medium & 12000 & $<14000$ & 39.76 \\
Large & 14000 & $<20000$ & 43.17 \\
Very large & 20000 & $<27000$ & 1.41 \\
\hline
\end{tabular}


TABLE 4. The 10 most resistant and 10 most susceptible genotypes of the 498 Evaluated in Uganda

\begin{tabular}{|c|c|c|c|c|c|c|c|c|c|c|c|c|c|c|}
\hline Genotype & Source & $\begin{array}{l}\text { Seed coat } \\
\text { colour }\end{array}$ & Seed size & $\begin{array}{l}100 \\
\text { seed } \\
\text { weight }\end{array}$ & $\begin{array}{l}\text { Initial } \\
\text { weight } \\
(\mathrm{mg})\end{array}$ & $\begin{array}{r}\text { Final } \\
\text { weight } \\
(\mathrm{mg})\end{array}$ & $\begin{array}{c}\% \\
\text { weight } \\
\text { loss }\end{array}$ & $\begin{array}{l}\text { Number } \\
\text { of eggs }\end{array}$ & $\begin{array}{l}\text { Number } \\
\text { of adults }\end{array}$ & $\%$ IE & $\begin{array}{l}\text { MDP } \\
\text { (days) }\end{array}$ & GI & DSI & \\
\hline AVRDC G 8527 & AVRDC (Taiwan) & Green & Small & 8335 & 4198 & 4197 & 0.02 & 24.00 & 2.67 & 6.31 & 27.00 & 0.07 & 0.70 & $\mathrm{R}$ \\
\hline PI G89 & AVRDC (Taiwan) & Cream & Medium & 12137 & 6402 & 6081 & 4.46 & 26.33 & 4.67 & 23.86 & 43.33 & 0.12 & 1.67 & $\mathrm{R}$ \\
\hline G 7955 & AVRDC (Taiwan) & Cream & Medium & 13031 & 6293 & 5839 & 7.08 & 131.00 & 35.33 & 44.27 & 25.67 & 0.95 & 1.82 & $\mathrm{R}$ \\
\hline Elite Lines 4.11-11 & Uganda & Cream & Large & 14407 & 6824 & 6623 & 3.10 & 42.67 & 20.33 & 32.66 & 26.67 & 0.63 & 2.05 & MR \\
\hline S-Lines 13.2A & Uganda & Cream/black & Small & 8455 & 3977 & 3842 & 3.44 & 140.00 & 12.00 & 7.18 & 23.67 & 0.36 & 2.12 & MR \\
\hline S-Lines 9.2 & Uganda & Cream & Small & 9566 & 6411 & 4926 & 15.94 & 52.00 & 14.00 & 17.58 & 24.33 & 0.38 & 2.12 & MR \\
\hline AVRDC SRE-B-15C & AVRDC (Taiwan) & Cream/black & Large & 16495 & 8248 & 8219 & 0.36 & 77.00 & 7.67 & 9.21 & 36.67 & 0.24 & 2.14 & MR \\
\hline PI G49 & AVRDC (Taiwan) & Green & Small & 11105 & 6928 & 5759 & 13.86 & 76.33 & 11.00 & 11.03 & 38.67 & 0.34 & 2.15 & MR \\
\hline AVRDC 8586 & AVRDC (Taiwan) & Green & Small & 11756 & 5866 & 5591 & 4.60 & 74.67 & 19.33 & 15.13 & 24.67 & 0.58 & 2.31 & MR \\
\hline PI G43 & AVRDC (Taiwan) & Cream/black & Medium & 12563 & 5881 & 5833 & 0.78 & 34.00 & 9.00 & 29.64 & 36.00 & 0.25 & 2.34 & MR \\
\hline BSPS 52 C-1 & Uganda & Cream & Large & 14324 & 7356 & 6041 & 17.26 & 187.00 & 125.33 & 69.50 & 29.33 & 4.43 & 7.01 & US \\
\hline BSPS 75B & Uganda & Yellow & Medium & 13426 & 6869 & 5134 & 25.05 & 184.30 & 112.33 & 61.02 & 29.00 & 3.87 & 7.12 & VS \\
\hline Bulindi 56 & Uganda & Cream & Medium & 12422 & 6129 & 4702 & 23.21 & 229.00 & 151.67 & 66.19 & 30.33 & 5.05 & 7.15 & VS \\
\hline Bulindi 31 & Uganda & Cream & Medium & 12639 & 6496 & 4947 & 23.90 & 239.30 & 160.00 & 66.82 & 30.67 & 5.21 & 7.19 & VS \\
\hline S-Lines 3.17 & Uganda & Cream/black & Small & 10368 & 7526 & 5974 & 20.66 & 272.70 & 149.67 & 69.45 & 30.00 & 5.00 & 7.24 & US \\
\hline Obs 116 & Uganda & Yellow & Large & 14757 & 7381 & 5848 & 20.78 & 312.30 & 146.33 & 47.08 & 29.67 & 4.95 & 7.31 & US \\
\hline USA 7 & USA & Yellow & Medium & 13662 & 6708 & 4896 & 27.18 & 290.70 & 172.33 & 60.47 & 30.33 & 5.75 & 7.31 & VS \\
\hline Bulindi 4B & Uganda & Yellow/green & Medium & 13162 & 7549 & 5712 & 24.37 & 282.30 & 157.67 & 56.22 & 31.00 & 5.37 & 7.33 & VS \\
\hline Bulindi 77B-1 & Uganda & Yellow & Medium & 13666 & 7033 & 5761 & 18.06 & 225.00 & 119.00 & 50.34 & 27.67 & 4.68 & 7.51 & VS \\
\hline AVRDC G 2043 & AVRDC (Taiwan) & Yellow & Large & 16726 & 8227 & 7342 & 10.82 & 216.70 & 93.33 & 40.73 & 24.00 & 4.18 & 8.14 & VS \\
\hline F.pr & & & & $<0.001$ & $<0.001$ & $<0.001$ & $<0.001$ & 0.595 & 0.001 & $<0.001$ & $<0.001$ & $<0.001$ & $<0.001$ & \\
\hline LSD $(0.05)$ & & & & 6272 & 941.4 & 1143.5 & 15.51 & 7.468 & 5.775 & 3.4987 & 0.073 & 1.065 & 3.2345 & \\
\hline
\end{tabular}

* Data was analysed for 498 genotypes but only the most resistant and very susceptible are presented for clarity. The Statistics is for the entire experiment (498 genotypes). R $=$ Resistant, MR = Moderate Resistant, $\mathrm{S}=$ Susceptible, VS = Very Susceptible, IE = Insect Emergence, MDP = Median Development Period, GI = Growth Index, DSI = Dobie Susceptibility Index 
seed size was observed on USA $33(5225 \mathrm{mg})$; (Table 4).

Bruchid injury and soybean seed weight loss. Genotype AVRDC G8527 had the least seed weight loss $(0.02 \%)$, followed by AVRDC SRE-B-15C $(0.36 \%)$; whereas USA 7 recorded $27.18 \%$ the highest seed weight loss $(\mathrm{P}<0.01)$, (Table 4). Out of the studied genotypes $45.38 \%$ had percent weight loss above the experimental mean (10.47) within 3 months of storage. The resistant genotypes had a mean weight loss of $3.85 \%$, the moderate resistant genotypes $5.44 \%$ and the susceptible genotypes $9.85 \%$; while the highly susceptible genotypes had a mean weight loss of $15.68 \%$.

\section{Bruchid population dynamics}

Oviposition. Callosobruchus chinensis laid eggs on all 498 studied genotypes. Over fifty percent of the studied genotypes had eggs less than experimental mean (136.1) (Table 4). Genotype OBS 116 had the highest number of egg counts (312), followed by NGDT 1.33-2 with 306 eggs; while AVRDC G8527 had the least number of eggs (24) (Table 4). However, there was no significant difference amongst genotypes on the number of eggs laid on them.

Magnitude of infestation. Genotype AVRDC G8527 had the least mean of adult emergence (2.67), while the highest mean was observed on USA 7 (172) (Table 4). The mean adult insect emergence for the resistant genotypes was 14.22; the moderate resistant 29.10, susceptible genotype 45.47 ; while the highly susceptible genotypes had a mean of 100.25 adults. Of the 498 studied genotypes, 52.41\% had the number of adult emergence below the experimental mean value of 64.53 .

Insect median development period. Results on median development periods (MDP) of the 498 studied genotypes are presented on Figure 2. Eighty-six percent of the genotypes had MDP range between 30-39 days, $13 \%$ had MDP range of 16-29 days, and 1\% had MDP range of 40-45 days. No genotype had MDP below 15 days; while $57.23 \%$ of the genotypes had MDP above the mean experimental mean (31.58 days). The predominant MDP was 31 days. Genotype G89 had the longest MDP of 43.33 days; followed by AVRDC G84051-31-

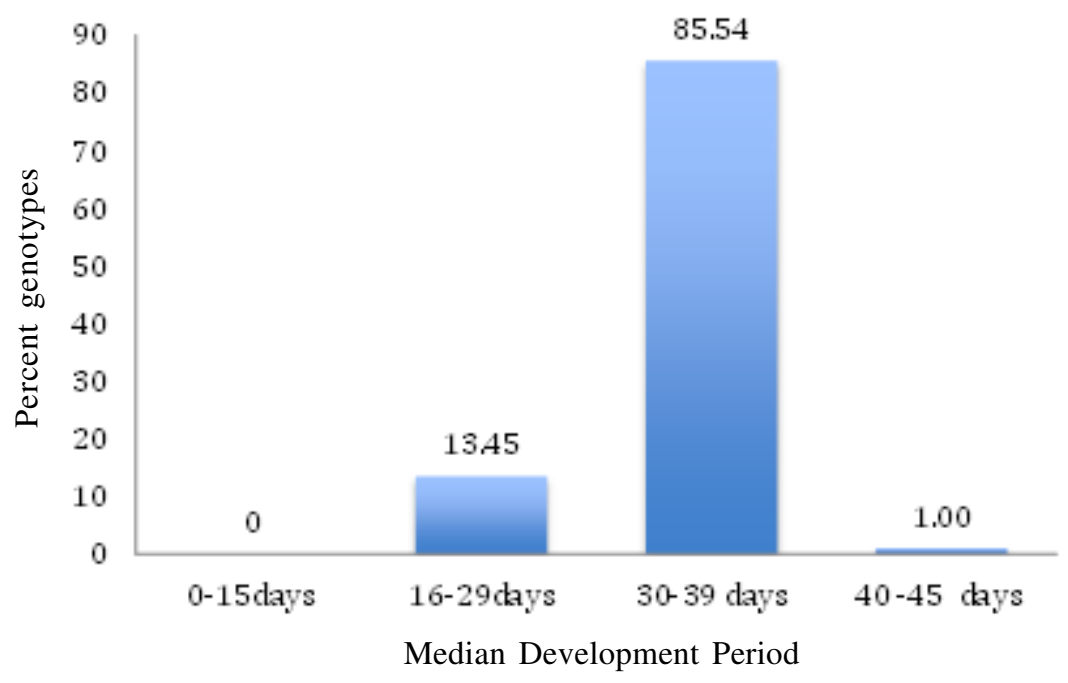

Figure 2. Median Development Periods for the 498 studied soybean genotypes in Uganda. 
2 (2) with 41 days; while Bulindi 12 had the least MDP of 18.67 days (Table 4).

Insect growth index. Out of the 498 genotypes, AVRDC G8527 had the least growth index $(\mathrm{GI}=0.066)$, followed by $\mathrm{G} 89$ with GI=0.124; whereas the highest GI was observed from USA 7 (GI=5.75) (Table 4). Fifty-three percent of the genotypes had GI below the experimental mean of 2.09 .

Correlations between variables. Results of correlation analysis are presented in Table 5. There were significant and strong positive correlations between adults that emerged with DSI (0.87), eggs (0.88), \% weight loss (0.73) and growth index (0.996). The same trait (adult emergence) also showed a significant positive correlation with insect emergence (0.59); and a weak but significant correlation (0.17) with median development period. DSI had a significant strong correlation with eggs $(0.77)$ and growth Index (0.86). Seed size (100 seed weight) had no correlation with DSI and MDP, but had very weak correlation with eggs, adults and GI.

The results of a simple linear regression analysis of percent seed weight loss against adult insect emergence are presented in Figure 3 . The results revealed that adult insect emergence would predict $62 \%\left(\mathrm{R}^{2}=0.624\right)$ of percent weight loss of seed. Regressing DSI against seed coat colour gave a significant relationship $(\mathrm{P}<0.001)$ and a strong coefficient of determination $\left(\mathrm{R}^{2}=71 \%\right)$ (Fig. 4).

Results from cluster analysis of the 27 most resistant and 14 most susceptible genotypes are presented by the dendrogram in Figure 5. Cluster analysis placed the genotypes into two major groups designated cluster I and cluster II, marked by vertical bars. Five sub-clusters are highlighted with brown dots. Genotypes from the same susceptibility category (DSI basis) are presented with the same font colour. Genotypes in red font are resistant to bruchids, black are moderate resistant and the genotypes in blue are the very susceptible. Cluster analysis revealed that the resistant genotype AVRDC G8527 was closely related to a moderate resistant genotype S-line 13.2A (Fig. 5). In cluster I, genotype AVRDC G4890-21-13-13 was very dissimilar from the entire group. Analysing its characteristics, AVRDC G489021-13-13 had a very high growth index (GI) as compared to other genotypes in the same group. Group II consisted only of susceptible genotypes, with Bulindi 14A and AVRDC G2043 being very similar to each other.

\section{DISCUSSION}

The results in this study demonstrated that soybean genotypes responded differently to $C$. chinensis infestation (Table 1), indicating that there is variability in genotypes resistance

TABLE 5. Correlation coefficients (r) for experimental parameters, under Callosobruchus chinensis no-choice artificial-infestation on the 498 genotype samples

\begin{tabular}{lccccccc}
\hline & $\begin{array}{c}100 \text { seed } \\
\text { weight }\end{array}$ & $\begin{array}{c}\% \text { weight } \\
\text { loss }\end{array}$ & $\begin{array}{l}\text { Number } \\
\text { of eggs }\end{array}$ & $\begin{array}{l}\text { Number } \\
\text { of adults }\end{array}$ & $\%$ IE & DSI & MDP \\
\hline \% weight loss & $0.0738^{*}$ & - & & & & & \\
Eggs & $0.0527^{*}$ & $0.6458^{* *}$ & - & & & & \\
Adults & $0.0559^{*}$ & $0.7316^{* *}$ & $0.875^{* *}$ & - & & & \\
$\%$ IE & $0.019^{\text {ns }}$ & $0.3573^{* *}$ & $0.2614^{* *}$ & $0.589^{* *}$ & - & & \\
DSI & $0.0419^{\text {ns }}$ & $0.5474^{* *}$ & $0.7711^{* *}$ & $0.8659^{* *}$ & $0.669^{* *}$ & - & \\
MDP & $-0.014^{\text {ns }}$ & $0.0551^{*}$ & $0.2024^{* *}$ & $0.1741^{* *}$ & $0.3865^{* *}$ & $0.41^{* *}$ & - \\
GI & $0.0603^{*}$ & $0.7293^{* *}$ & $0.8669^{* *}$ & $0.9962^{* *}$ & $0.5828^{* *}$ & $0.86^{* *}$ & $0.14^{* * *}$ \\
\hline
\end{tabular}

** Significant at $\mathrm{P}<0.01 ; *$ Significant at $\mathrm{P}<0.05 ; \mathrm{ns}=$ Not significant. \% IE = Percent Insect Emergence; $\mathrm{DSI}=$ Dobie susceptibility Index; MDP = Median Development Period 


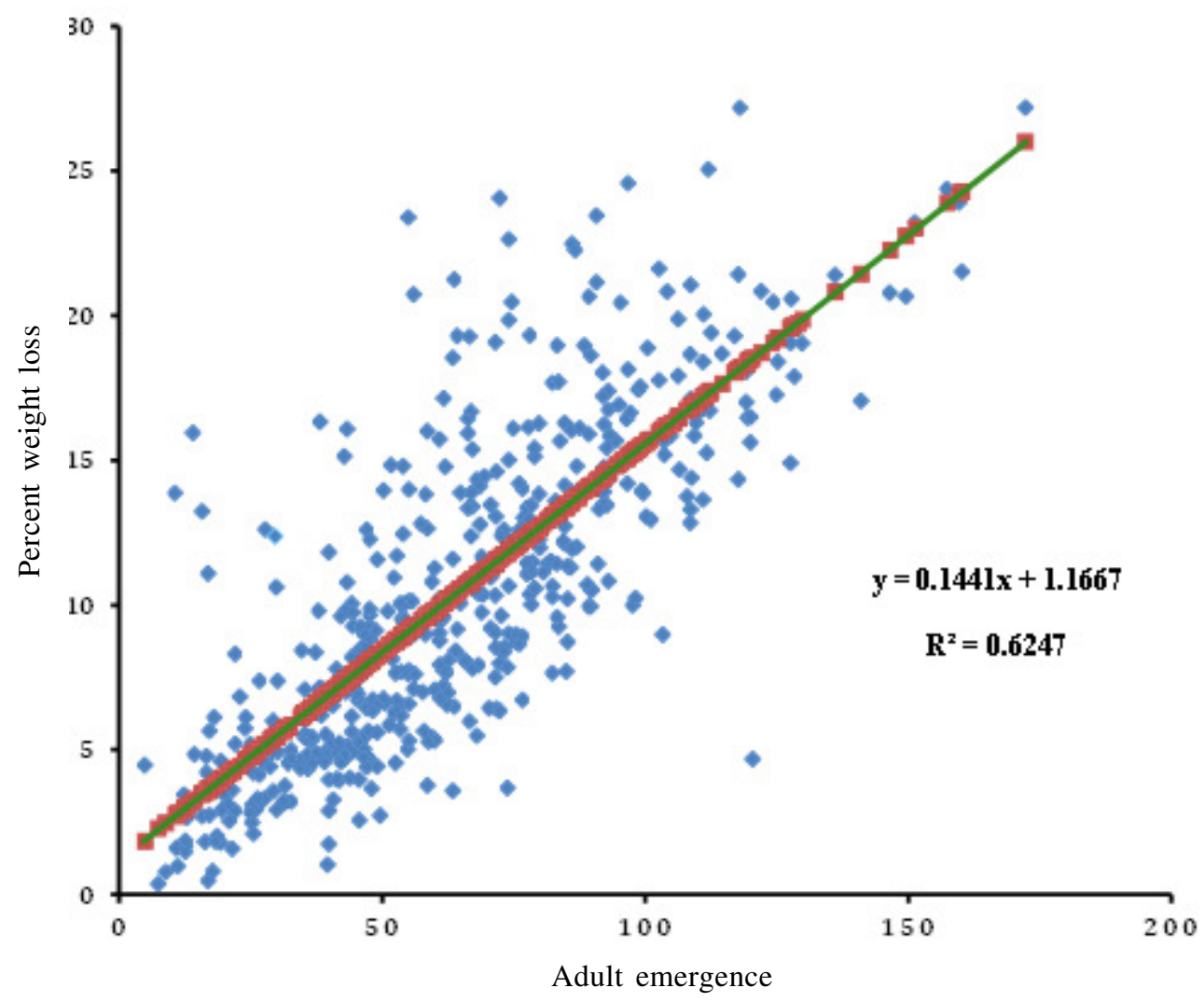

Figure 3. Regression of percent seed weight loss of soybean against adult insect emergence for the 498 genotypes.

levels. The variation in genotype resistance was basically due to variations in adult emergence, percent weight loss, median development period and growth index. The study identified three genotypes as resistant to $C$. chinensis, which therefore can confer the resistant gene for soybean breeding programmes. Since less than $1 \%$ of the genotypes was resistant, it implied that the search for resistance gene sources might have to go further. This is in agreement with Dong et al. (2001), who reported that sources of resistance to bruchids from cultivated legumes are low.

Relative susceptibility. The DSI indicated existence of genetic diversity among tested genotypes and thus the germplasm collection could provide parent materials for genetic studies. Mechanisms of resistance were beyond the scope of this study, but with the present findings, it can be speculated that the genotypes possess different intrinsic and extrinsic factors of different levels, which conferred different resistance levels either through antibiosis, antixenosis or both. Osman et al. (1991) reported that resistance to bruchids in soybean was due to presence of saponins, anti-nutritional factors, high fat and protein content which inhibit larval development. Osman et al. (1991) further reported that both antixenosis and antibiosis mechanisms were important in the soybean resistance to bruchids. Similar findings were reported by Lephale et al. (2012) in beans and Amusa et al. (2013) in cowpea.

Bruchid injury and soybean seed weight loss. The postulate of variability in soybean 


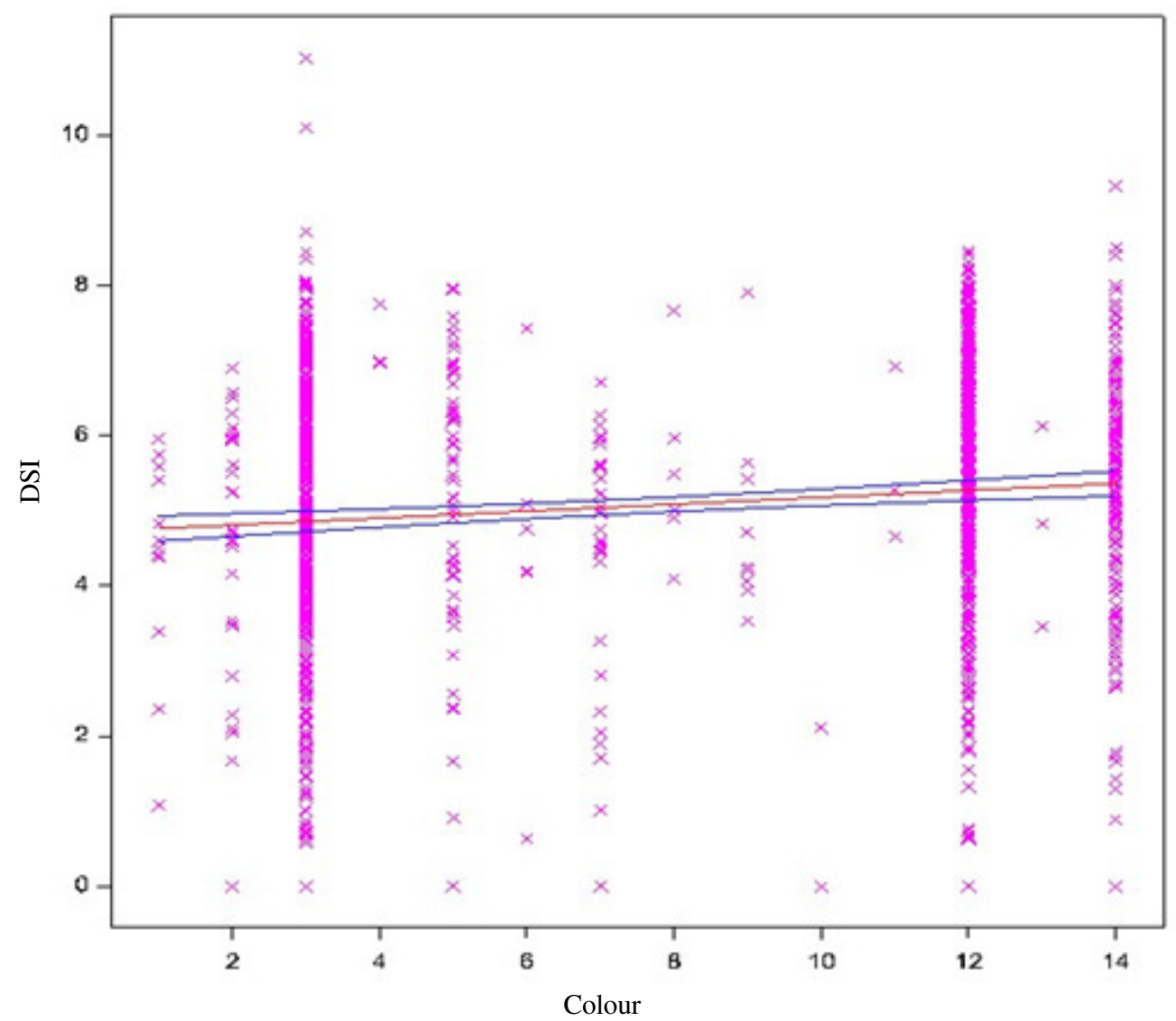

Colour key:

1 = Black, 2 = Brown, 3 = Cream, 4 = Imperfect black, $5=$ Cream/green, 6 = Cream/yellow, $7=$ Green, $8=$ Green/ cream, $9=$ Green/yellow, $10=$ Green brown, $11=$ Variegated, $12=$ Yellow, $13=$ Yellow brown, $14=$ Yellow $/$ green

Figure 4. Regression of DSI against seed coat colour for the 498 studied genotypes.

genotypes reaction to $C$. chinensis infestation was further highlighted by variation among genotypes in percent weight loss (Table 4). The resistant genotypes were not immune to C. chinensis, but suffered considerably less weight loss compared to the susceptible genotypes. Weight loss is an economic loss indicator and an economic loss of $10.47 \%$ within three months of storage implies that if soybean is to be stored for long periods, some form of protective measure has to be used to avoid enormous yield losses. The percent seed weight loss observed in this study was higher than the reported loss by Sharma and Thakur (2014a), which was $4.93 \%$. Reports on losses due to bruchid damage vary from crop to crop
(Sharma and Thakur, 2014b; Ebinu et al., 2016) and genotype to genotype (Sharma and Thakur, 2014c; Gevina et al., 2016). For example, common beans in Malawi have been reported to incur losses of up to $38 \%$, Uganda reported up to 8\%; while Kenya and Tanzania reported as high as $78 \%$ within six months of storage (Kananji, 2007).

\section{Bruchid population dynamics}

Oviposition. Lack of significant difference among genotypes for number of eggs laid, implied that the genotypes did not influence oviposition by female bruchids. The other finding was that no genotype was totally 


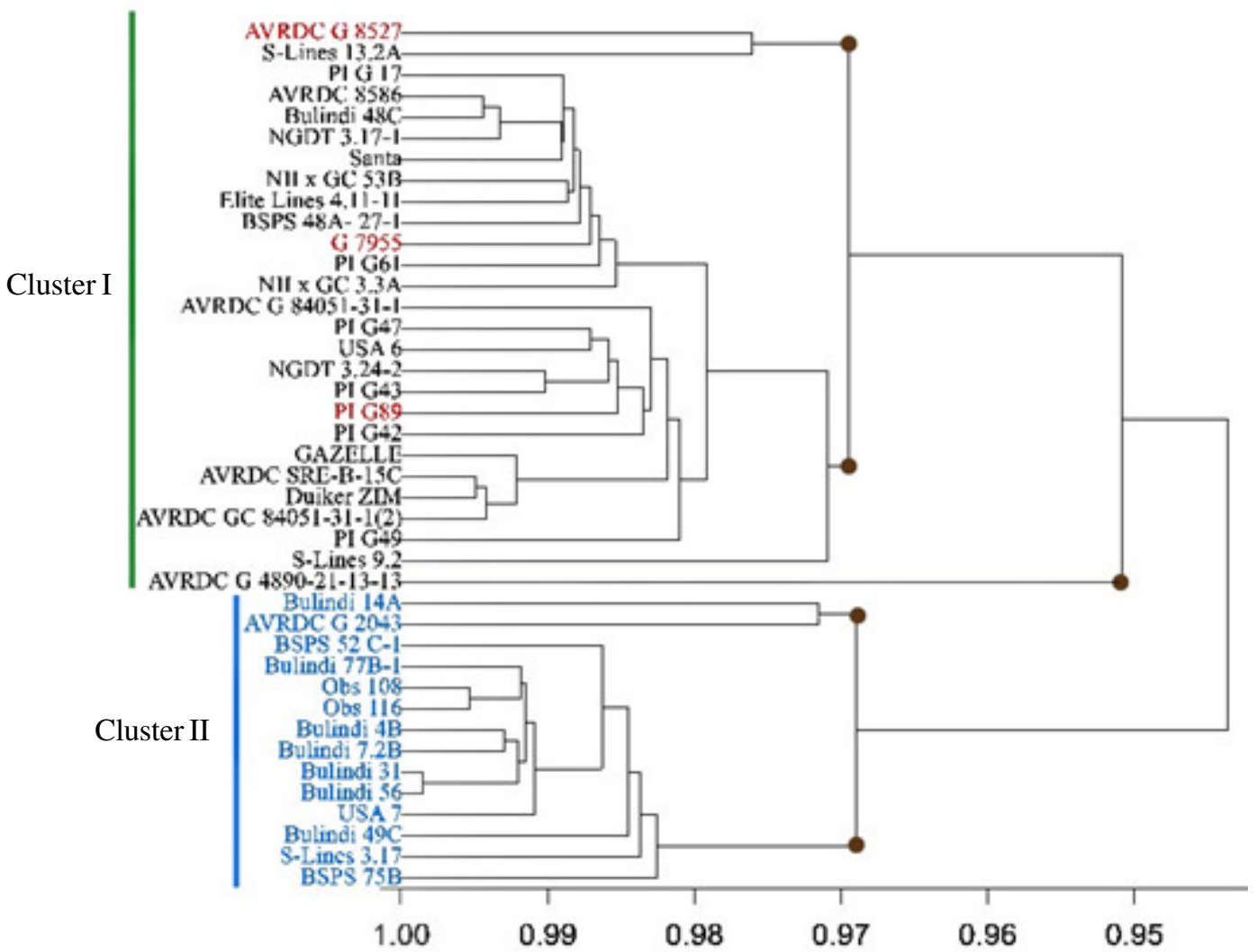

Figure 5. Dendrogram showing relationships amongst 27 most resistant and 15 most susceptible genotypes.

rejected for oviposition. Results of this study demonstrated that oviposition trait alone failed to distinguish genotype suitability for $C$. chinensis development. This finding was in agreement with the theory that where the insects have no choice, females oviposit on hosts in which the chances for larval survival are low or absent (König et al., 2016). This behaviour is basically associated with unpredictability of the environmental resources. Furthermore, results indicate that resistance to $C$. chinensis in soybean might be in the seed or seed coat and that the nature of resistance might be antibiosis and not antixenosis. Somta et al. (2006) and Swella and Mushobozy (2009) reported that Callosobruchus spp could oviposit on any seed, even though the seed might not be suitable for development of insects. Amusa et al. (2014) reported that the number of eggs laid by insects was less important than the rate of oviposition in its influence of the rate of multiplication. However, the number of eggs laid helped to know whether there was a likelihood of getting adults since no adults would emerge from zero laid eggs (Azeez and Pitan, 2014).

Magnitude of infestation. Number of adult emergence indicates the magnitude of infestation and the loss of market value of the crop (Emeka, 2010). The resistant genotypes like AVRDC G8527 were characterised by delayed and low adult emergence; while in susceptible genotypes, the adult emergence was relatively early, extremely rapid and in high numbers. Each adult emerging leaves a hole on the seed, which implies loss of appeal in the market (Kananji, 2007), and could lead to loss of seed viability (Kumar and Kalita, 2017). 
It can be speculated that genotype variations in magnitude of infestation by bruchids observed in this study could be due to differences in antinutritional factors (Amusa et al., 2014).

Insect median development period. Results of median development periods indicated variability in the genotypes, with genotypes PI G89 and AVRDC G84051-31-2 (2) having the longest development periods (Table 4) indicating that such genotypes probably were either hard-textured (Soumia, 2015) and difficult to ingest or digest for the larvae; partially toxic (Gevina et al., 2016); and/or nutritionally inadequate to support optimal development rates of the pest (Hiiesaar et al., 2009). Kananji (2007) and Hiiesaar et al. (2009) suggested that extended development period was due to antibiosis or anti-feedant activity which could be the actual resistance mechanism. The results also indicated shorter development periods compared to results of Sharma and Thakur (2014a), who reported it to be 40-50 days, implying that soybean can no longer be stored safely for more than a month without some form of protection in Uganda. This finding has a negative impact on the farmers who would be forced to sell their produce as soon as they harvest even when the market prices are still low to avoid incurring losses.

Insect growth index. The results on insect growth index (Table 4) which is an indicator of genotype suitability to Callosobruchus chinensis development, showed that the insect had the capacity to infest and develop on all soybean genotypes tested but with significant differences. Larval development within the seed depends on chemical composition of the grain (Sharma and Thakur, 2014c). The inability of $C$. chinensis to develop at the same rate in the genotypes would be an indication that genotypes had varying contents of saponin (Swella and Mushobozy, 2009), fat content (Tripathi et al., 2013) and proteincarbohydrates ratio (Srinivasan and Durairaj,
2007). Maximum growth of $C$. chinensis was on genotype USA 7, implying that this genotype had the least anti-nutritional factors and, therefore, was the most suitable genotype for development of the bruchid; while AVRDC G8527 had the most anti-nutritional factors which made it the least suitable.

Correlations between variables. Absence of significant correlation between 100 seed weight and DSI in this study (Table 5) implied that the association between these two variables was curvilinear or non-linear. This explanation was true for all other non- significant associations, with correlation coefficients closer to zero. Furthermore, these results suggested that resistance in soybean did not really depend on the nutritional factors nor space but presence of anti-nutritional factors which may not depend on the seed size or seed density (Sharma and Thakur, 2014c). The weak correlation between 100 seed weight with eggs and adults suggested that oviposition and adult emergence did not depend on 100 seed weight which was similar to what Dent (2000) reported that seed weight was a very complex variable in legumes and as such it does not have linear relationships with other variables (Acquaah, 2007).

The correlation coefficients (Table 5) suggested that the number of adults' emergence could be used for predicting resistance in soybean because it had an almost perfect positive correlation with growth index and strong correlation with DSI. Similar findings were reported by Kananji (2007), who worked on beans and Hiruy and Getu (2018) on maize. Results on strong positive correlation between GI with percent weight loss indicated that rapid insect growth and development could lead to high percent seed weight losses. On the other hand, resistant genotypes reduced the number of adult insects emergence thereby minimising the post harvest losses. If the resistance in the lines with low GI could be enhanced it would be an environmental friendly way of reducing losses from C. chinensis. 
Regression analysis of percent seed weight loss against adult insect emergence (Fig. 3) implied that post harvest losses due $C$. chinensis increased with increase in adult emergence which eventually would lead to increased economic losses. Further more, insect adult emergence explained $62 \%$ of the variability in percent seed weight loss. The information generated is important for determining economic injury levels for $C$. chinensis in soybean in Uganda. Tefera et al., (2011) and Musa et al. (2015) reported that increased adult emergence produces a corresponding increase in percent weight loss in grains until there is no more food for larva development in the grains. Results on regression of DSI against seed coat colour for 498 genotypes (Fig. 4) indicated that seed coat colour explained $74 \%$ of the variability in seed resistance therefore seed coat colour could be one of traits used to predict resistance of soybean to $C$. chinensis. The results were in agreement with El-Hamid et al. (2008).

Results from cluster analysis of 27 most resistant and 15 most susceptible selected genotypes (Fig. 5) implied that geographical distances between sources of accessions were not associated with genetic distances among genotypes. However, the genetic gap between resistant and susceptible genotypes was evident suggesting that the variability was an important trait for classification of germplasm. The similarity of genotype AVRDC G8527 to S-line 13.2A suggest that these lines would be equally used as sources of resistance genes to C. chinensis.

\section{ACKNOWLEDGEMENT}

The authors acknowledge the Intra-ACP (CSAA) Mobility Scheme for offering the first author a $\mathrm{PhD}$ scholarship during which this study was conducted. This research was made possible through financial support provided by Carnegie Cooperation of New York, through the Regional Universities Forum for Capacity Building in Agriculture (RUFORUM).

\section{REFERENCES}

Acquaah G. 2007. Principles of plant genetics and breeding. Blackwell Publishing, Australia. 151pp.

Affognon, H.D., Njoroge, A.W., Mutungi, C.M., Manono, J., Baributsa, D. and Murdock. L.L. 2016. Storage of pigeonpea grain (Cajanus cajan (L.) Millsp.) in hermetic triple-layer bags prevents losses caused by Callosobruchus maculatus (F.) (Coleoptera: Bruchidae). Acta Horticulturae 1120: 245-51. https://doi.org/ 10.17660/ActaHortic. 2016.1120.37.

Amusa, O.D, Adebayo, L.O., Kehinde, B. and Omoche, O. 2013. Evaluation of four cowpea lines for bruchid (Callosobruchus maculatus) tolerance. Journal of Natural Sciences Research 3(13):2225-3186.

Amusa, O.D., Ogunkanmi L.A., Adetunbi, J.A., Akinyosoye, S.T., Bolarinwa, K.A. and Ogundipe, O.T. 2014. Assessment of bruchid (Callosobruchus maculatus) tolerance of some elite cowpea (Vigna unguiculata) varieties. Journal of Agriculture and Sustainability 6(2):164-78. Azeez, O.M. and Pitan, O.O.R. 2014. Comparative seed resistance in eighty cowpea accessions to the seed bruchid, Callosobruchus maculatus (Fabricius) (Coleoptera: Bruchidae). Archives of Phytopathology and Plant Protection 47 (15):1806-14.

Bansal, R., Tae-Hwan J., Mian M.A.R. and Michel. A.P. 2013. Developing host-plant resistance for Hemipteran soybean pests: Lessons from soybean aphid and stink bugs. INTECH Open Access Publisher. https://doi.org/10.5772/3384.

Credland, P.F. 2000. Bioassays with bruchid beetles: Problems and (some) solution. Proceedings of the 6th International Working Conference on Seed Product Protection 6:21-27.

Dent, D. 2000. Insect pest management. $2^{\text {nd }}$ Edition. CABI Publishing, Wallingford, UK. pp. 20-81. 
Deshpande, V.K., Makanur, B., Deshpande, S., Adiger, S. and Salimath, P.M. 2011. Quantitative and qualitative losses by Callosobruchus maculatus. Plant Archives 11:723-731.

Dong, Y.S., Zhuang, B.C., Zhao, L. M. Sun, H. and He, M.Y. 2001. The genetic diversity of annual wild soybeans grown in China. Theoretical and Applied Genetics 103(1): 98-103. https://doi.org/10.1007/s00122 0000522.

Ebinu, J. A., Nsabiyera, V., Otim, M., Nkalubo, S.T., Ugen, M. and Agona, A.J. 2016. Susceptibility to bruchids among common beans in Uganda. African Crop Science Journal 24(3):289-303. http://dx.doi.org/ 10.4314/acsj.v24i3.6

El-Hamid, M.A., El-Bramawy, S., El-Sayed, S. and El-Hendawy W.I. 2008. Assessing the suitability of morphological and phenological traits to screen (sesame genotypes for fusarium wilt and charcoal rot disease resistance. Journal of plant Protection Research 48(4):397-410.

Emeka, O. 2010. The effects of different infestation levels of Callosobruchus maculatus F. on stored cowpea (Vigna unguiculata Walp). http://dx.doi.org/ 10.2139/ssrn. 1547005

Farrell, J., Brier, H. and Colins, P. 2015. Diagnostic protocols: Diagnostic methods for cowpea weevil or cowpea bruchid (Callosobruchus maculatus). Queensland Primary Industries and Fisheries. Kingaroy, Queensland. http://www.padil.gov.au/pbt

Fungo, B., Grunwald, S. , Tenywa, M.M, Vanlauwe, B. and Nkedi-Kizza, P. 2011. Lunnyu Soils in the Lake Victoria Basin of Uganda: Link to toposequence and soil type. African Journal of Environmental Science and Technology 5:15-24.

Gevina, S., Kennedy, J.S., Mohan, S. and Senthil, N. 2016. Development and damage assessment of the storage beetle, Callosobruchus Maculatus. under normal and controlled conditions. Proceedings of the $10^{\text {th }}$ International Conference on controlled atmosphere and Fumigation in stored products (CAF2016).Winnipeg, Canada. pp. 25-31. www.researchgate.net. Harding, S. and Payne, R. 2012. Guide to multivariate analysis in GenStat. VSN International,UK. http://www.genstat. co.uk/. pp. 27-36.

Hiiesaar, K., Švilponis, E., Metspalu, L., Jõgar, K., Mänd, M., Luik, A. and Karise R. 2009. Influence of neem-azal T/S on feeding activity of colorado potato beetles (Leptinotarsa Decemlineata Say). Agronomy Resesearch 7 (1):251-256.

Hiruy, B. and Getu, E. 2018. Screening of some maize varieties for resistance against the maize weevils, Sitophilus Zeamais (Motsch.). International Journal of Entomology and Nematology 4 (1):77-84.

Kananji, G. 2007. A study of bruchid resistance and its inheritance in Malawian dry bean germplasm. PhD Thesis. University of KwaZulu-Natal. Republic of South Africa. pp. 77-111.

Kar, A. and Ganguli, J. 2016. Fecundity and preferential oviposition by pulse beetle, Callosobruchus maculatus F. on chickpea (Cicer arietinum L.) Var Dollar. Legume Research 39(2):310-14. https://doi.org/ 10.18805/lr.v0iOF.6770.

König, M.A.E., Wiklund, C. and Ehrlén, J. 2016. Butterfly oviposition preference is not related to larval performance on a polyploid Herb. Ecology and Evolution 6(9):278189. https://doi.org/10.1002/ece3.2067.

Kumar, D. and Kalita, P. 2017. Reducing postharvest losses during storage of grain crops to strengthen food security in developing countries. Foods 6 (1): 8. https:/ /doi.org/10.3390/foods6010008.

Lephale, S., Addo-Bediako, A. and Ayodele, V. 2012. Susceptibility of seven cowpea cultivars (Vigna unguiculatus) to cowpea beetle (Callosobruchus Maculatus). Agricultural Science Research Journals 2 (2):65-69. http://www.resjournals.com/ ARJ. 
Musa, A.K. and Adeboye, A.A. 2017. Susceptibility of some cowpea varieties to the seed beetle Callosobruchus maculatus (F.) (Coleoptera: Chrysomelidae). Journal of Agricultural Sciences 62(4):351-360.

Onyido, A.E., Zeibe, C.C., Okonkwo, N.J., Ezugbo-Nwobi, C.M., Egbuche, O.I., Udemezue, B. and Ezeanya, L.C. 2011. Damage caused by the bean bruchid, Callosobruchus maculatus (Fabricius) on different legume seeds on sale in Awka and Onitsha markets, Anambra State, South Eastern Nigeria. African Research Review 5 (21): 116-23.

Osman, N., Rohani, I. and Abang, B.A. 1991. Damage assessment on stored mungbean (Vigna Radiata) L. Wilczek and Soybean (Glycine max) L . Merr infested with the common bean weevil, Callosobruchus maculatus ( F .) ( Coleoptera: Bruchidae) Pertanika 14(1):27-30.

Radha, R. and Susheela, P. 2014. Studies on the life history and Ovipositional preference of Callosobruchus maculatus reared on different pulses. Research Journal of Animal, Veterinary and Fishery Sciences 2 (6): $1-5$.

Régnière, J., Powell, J., Bentz B. and Nealis, V. 2012. Effects of temperature on development, survival and reproduction of insects: Experimental design, data analysis and modeling. Journal of Insect Physiology 58:634-647.

Sharma, S. and Thakur, D.R. 2014a. Biochemical basis for bruchid resistance in cowpea, chickpea and soybean genotypes. American Journal of Food Technology 9(6):318-324. https://doi.org/ 10.3923/ajft.2014.318.324.

Sharma, S. and Thakur, D.R. 2014b. Comparative developmental compatibility of Callosobruchus maculatus on cowpea, chickpea and soybean genotypes. Asian Journal of Biological Sciences 7(6):270 76. https://doi.org/10.3923/ajbs.2014. 270.276 .
Sharma, S. and Thakur, D.R. 2014c. Studies on the varietal preference of Callosobruchus macualtus on soybean genotypes. Asian Journal of Biiological Sciences 7(5):233-237. https://doi.org/ 10.3923/ajbs.2014.233.237.

Somta, P., Talekar, N. S. and Srinives, P. 2006. Characterization of Callosobruchus chinensis (L.) resistance in Vigna umbellata (Thunb.) Ohwi and Ohashi. Journal of Stored Products Research 42(3):313-327. https://doi.org/10.1016/j.jspr.2005.05.003.

Somta, P., Kaga, A., Tomooka, N., Isemura, T., Vaughan, D.A. and Srinives, P. 2008. Mapping of quantitative trait loci for a new source of resistance to bruchids in the wild species Vigna Nepalensis Tateishi ad Maxted (Vigna Subgenus Ceratotropis). Theoretical and Applied Genetics. 17(4):621-628. https://doi.org/10.1007/ s00122-008-0806-3.

Soumia, P.S. 2015. Factors for resistance in mung bean, Vigna radiata against Callosobruchus spp. Division of Entomology Indian Agricultural Research Institute New Delhi-110012, India.

Spradbery, P. 2013. Invasive species compendium: Callosobruchus chinensis. www.cabi.org/isc/https://doi.org/10.1094/ PDIS.

Srinivasan, T. and Durairaj, C. 2007. Biochemical basis of resistance in rice bean, Vigna umbellata Thunb. (Ohwi and Ohashi) against Callosobruchus maculatus F. Journal of Entomology 4(5):371-78. https://doi.org/10.3923/je.2007.371.378.

Sserumaga. 2015. G X E interactions and agronomic performance of doubled haploids testcross maize (Zea mays) hybrids Euphytica: International Journal of Plant Breeding.Doi 10.1007/s10681-015-1549-2

Swella, G. B. and Mushobozy, D.M.K. 2009. Comparative susceptibility of different legume seeds to infestation by cowpea bruchid Callosobruchus maculatus (F.) (Coleoptera: Chrysomelidae). Plant Protection Science 45(1):19-24. 
Tembo, L., Pungulani, L. Mataa, J., Sohati, P.H. and Munyinda, K. 2016. Developing cowpea and bean genotypes with tolerance to bruchid beetle. RUFORUM Working Document Series 14(1):879-883. http:// repository.ruforum.org.

Tefera, T., Mugo, S. and Likhayo, P. 2011. Effects of insect population density and storage time on grain damage and weight loss in maize due to the maize weevil Sitophilus zeamais and the larger grain borer Prostephanus truncatus. African Journal of Agricultural Research 6(10): 2249-2254. http://www.academicjournals.org/AJAR (ISSN 1991-637X 2).

Tripathi, K. Shashi B., Srinivasan, K., Prasad, T.V. and Gautam, R.D. 2013. Physical and biochemical basis of resistance in cowpea (Vigna unguiculata Walp.) accessions to pulse-beetle, Callosobruchus chinensis ( L.)
International Journal of Legume Research 36(5):457-466.

Tukamuhabwa, P. and Oloka, H.K. 2016. Soybean research and development in Uganda: A case of paradigm shift in African Universities. Makerere University Research Institute Kabanyolo. Kampala, Uganda. pp. 22-29.

War, A.R., Surya, M., Venkata, N., Boddepalli, S., Srinivasan, R. and Ramakrishnan, M.N. 2017. Mechanism of resistance in mungbean [Vigna radiata (1.) r. wilczek var. radiata] to bruchids, Callosobruchus spp. (Coleoptera: Bruchidae). Frontiers in Plant Science 8:1031. https://doi.org/ 10.3389/fpls.2017.01031.

Yamane, T. 2013. Biorational control methods for protection of stored grain legumes against bruchid beetles. Agricultural Sciences 4(12):762-766. https://doi.org/ 10.4236/as.2013.412104. 